\title{
ARTICLE
}

\section{Long-term effect of modification of dietary protein intake on the progression of diabetic nephropathy: a randomised controlled trial}

\author{
D. Koya $\cdot$ M. Haneda $\cdot$ S. Inomata $\cdot$ Y. Suzuki $\cdot$ \\ D. Suzuki • H. Makino $\cdot$ K. Shikata $\cdot$ Y. Murakami • \\ Y. Tomino $\cdot$ K. Yamada $\cdot$ S. I. Araki • A. Kashiwagi • \\ R. Kikkawa • \\ on behalf of the Low-Protein Diet Study Group
}

Received: 24 December 2008 / Accepted: 15 June 2009 /Published online: 4 August 2009

(C) The Author(s) 2009. This article is published with open access at Springerlink.com

\begin{abstract}
Aims/hypothesis There is currently insufficient evidence to recommend a low-protein diet for type 2 diabetic patients with diabetic nephropathy. We assessed whether a low-protein diet could prevent the progression of diabetic nephropathy.

Methods This was a multi-site parallel randomised controlled trial for prevention of diabetic nephropathy progression among 112 Japanese type 2 diabetic patients with overt nephropathy. It was conducted in Japan from 1 December
\end{abstract}

Other members of the Low-Protein Diet Study Group are listed in Electronic supplementary material

Electronic supplementary material The online version of this article (doi:10.1007/s00125-009-1467-8) contains supplementary material, which is available to authorised users.

\section{Koya $(\bowtie)$}

Division of Endocrinology and Metabolism,

Kanazawa Medical University,

Uchinadacho, Kahokugun,

Ishikawa 920-0293, Japan

e-mail: koya0516@kanazawa-med.ac.jp

M. Haneda

Department of Medicine, Asahikawa Medical College,

Asahikawa, Japan

\section{S. Inomata}

Akita Medical Center,

Akita, Japan

\section{Y. Suzuki}

School of Health Sciences, Factory of Medicine,

Niigata University,

Niigata, Japan

D. Suzuki

Department of Medicine, Tokai University,

Isehara, Japan
1997 to 30 April 2006. The participants were randomly assigned using a central computer-generated schedule to either low-protein diet $\left(0.8 \mathrm{~g} \mathrm{~kg}^{-1}\right.$ day $\left.^{-1}\right)$ and normal-protein diet $\left(1.2 \mathrm{~g} \mathrm{~kg}^{-1} \mathrm{day}^{-1}\right)$, and were followed for 5 years. The participants and investigators were not blinded to the assignment. The primary outcomes were the annual change in estimated GFR and creatinine clearance, the incidence of doubling of serum creatinine and the time to doubling of baseline serum creatinine.

\section{H. Makino $\cdot$ K. Shikata}

Department of Medicine and Clinical Science,

Okayama University Graduate School of Medicine,

Okayama, Japan

Y. Murakami · S. I. Araki · A. Kashiwagi · R. Kikkawa

Shiga University of Medical Science,

Otsu, Japan

\section{Y. Tomino}

Division of Nephrology, Juntendo University,

Tokyo, Japan

K. Yamada

Metabolic Disease Clinic,

Chiba, Japan 
Results The study was completed by 47 (84\%) of 56 participants in the low-protein diet group and 41 (73\%) of 56 participants in the normal-diet group. During the study period, the difference in mean annual change in estimated GFR between the low-protein diet and the normal-protein diet groups was $-0.3 \mathrm{ml} \mathrm{min}{ }^{-1} 1.73 \mathrm{~m}^{-2}$ (95\% CI -3.9, 4.4; $p=0.93)$. The difference in mean annual change in creatinine clearance between the low-protein diet and the normal-protein diet groups was $-0.006 \mathrm{ml} \mathrm{s}^{-1} 1.73 \mathrm{~m}^{-2}$ (95\% CI $-0.089,0.112 ; p=0.80)$. A doubling of serum creatinine was reached in 16 patients of the low-protein group (34.0\%), compared with 15 in the normal-protein group (36.6\%), the difference between groups being $-2.6 \%$ (95\% CI $-22.6,17.5 ; p=0.80)$. The time to doubling of serum creatinine was similar in both groups $(p=0.66)$.

Conclusions/interpretation It is extremely difficult to get patients to follow a long-term low-protein diet. Although in the low-protein group overall protein intake was slightly (but not significantly) lower, it did not confer renoprotection.

Clinical trial registration: ClinicalTrials.gov NCT 00448526 Funding: Research grant from the Ministry of Health, Labour and Welfare of Japan

Keywords Albuminuria - Diabetic nephropathy · eGFR . Low-protein diet $\cdot$ Proteinuria

$\begin{array}{ll}\text { Abbreviations } \\ \text { ACE-I } & \text { ACE inhibitors } \\ \text { ARBs } & \text { Angiotensin II receptor blockers } \\ \text { eGFR } & \text { Estimated GFR } \\ \text { ESRD } & \text { End-stage renal disease } \\ \text { MDRD } & \text { Modification of Diet in Renal Disease study }\end{array}$

\section{Introduction}

Diabetic nephropathy develops in $40 \%$ of patients with diabetes and, in spite of progress in new treatment for diabetes and anti-hypertensive drugs, is the leading cause of end-stage renal disease (ESRD) worldwide [1-3]. Diabetic nephropathy is also closely associated with higher cardiovascular mortality rates [4]. Therefore, additional efforts are needed to arrest the progression of diabetic nephropathy.

A low-protein diet slows the progression of renal disease and improves survival in patients with various glomerulopathies, including diabetic kidney disease [5]. Clinically, a meta-analysis suggested that low-protein diet lowers the incidence of ESRD or death in patients with non-diabetic nephropathies [6]. Another meta-analysis of 108 patients with type 1 diabetes in five studies (mean follow-up
4.5-35 months) showed the benefit of low-protein diet in slowing the progression of diabetic nephropathy [7]. Indeed, a low-protein diet is recommended as nutritional management of diabetic nephropathy [8], although there is insufficient evidence to suggest that such a diet improves renal dysfunction $[9,10]$. The landmark study of nondiabetic kidney disease, the Modification of diet in renal disease study (MDRD), also failed to reach a conclusion regarding the benefits of a low-protein diet in reducing risk of ESRD or death [11, 12]. Furthermore, extended followup after the MDRD trial also failed to show a significant benefit of low-protein diet in slowing the development of ESRD and all-cause mortality [13].

To explore the uncertainties on effectiveness of lowprotein diet, we conducted a randomised controlled trial to determine the effect of low-protein diet on the progression of renal dysfunction and albuminuria in type 2 diabetic patients with overt nephropathy.

\section{Methods}

Study design This was a multi-site randomised controlled trial for prevention of diabetic nephropathy progression among 112 type 2 diabetic patients, who were aged 30 to 70 years and had overt nephropathy. The trial was conducted from 1 December 1997 to 30 April 2006. After a baseline run-in period (3 months), the patients were monitored for 5 years. The protocol was approved by the institutional review boards of each centre. All participating patients provided written, informed consent. Before the present study, 41 diabetic patients with overt nephropathy had been randomly assigned to normal protein intake $(n=21)$ and low protein intake $(n=20)$ groups. This 1 year feasibility trial was completed by 34 patients. Daily protein intake in the feasibility study was $1.22 \pm 0.25 \mathrm{~g} \mathrm{~kg}^{-1}$ day $^{-1}$ (normal) and $0.92 \pm 0.43 \mathrm{~g} \mathrm{~kg}^{-1} \mathrm{day}^{-1}$ (low protein) and the difference was statistically significant $(p<0.05)$. Based on these data, sample size for the present study was calculated. To achieve $90 \%$ power with a $5 \%$ significance level, we found that least 31 participants per group would be necessary. To account for drop-out due to trial duration, a 100 participants (50 per group) were planned for analysis.

Participants The participants were Japanese men and women, aged 30 to 70 years. All had type 2 diabetes (defined according to World Health Organization criteria) of at least 5 years duration and were being treated by diet or by diet plus oral hypoglycaemic agents or insulin injection. Other inclusion criteria were: (1) urinary protein excretion more than $1 \mathrm{~g} /$ day but less than $10 \mathrm{~g} /$ day; (2) urinary albumin excretion rate of more than $200 \mu \mathrm{g} / \mathrm{min}$ at least twice in a 1 year period; (3) serum creatinine below 
$176 \mu \mathrm{mol} / \mathrm{l}$; (4) at least simple diabetic retinopathy; and (5) on normal-protein diet $\left(1.2 \mathrm{~g} \mathrm{~kg}^{-1} \mathrm{day}^{-1}\right)$. Potential participants were excluded if they had: type 1 diabetes; other renal diseases; body weight less than $80 \%$ of ideal body weight; clinically significant illness such as congestive heart failure, hepatic disease, recent myocardial infarction and stroke, and urinary tract infection; or if they were being treated with a low-protein diet $\left(0.8 \mathrm{~g} \mathrm{~kg}^{-1} \mathrm{day}^{-1}\right)$ and/or ACE inhibitors (ACE-I) or angiotensin II receptor blockers (ARBs). Hypertension was defined as blood pressure $\geq 140 / 90 \mathrm{mmHg}$ or use of anti-hypertensive drugs.

Randomisation and intervention During the 3 month screening period, the participants continued to take a normal-protein $\operatorname{diet}\left(1.2 \mathrm{~g} \mathrm{~kg}^{-1} \mathrm{day}^{-1}\right)$ and their usual medications. They were then randomly assigned at a central location to follow either a low-protein diet $\left(0.8 \mathrm{~g} \mathrm{~kg}^{-1} \mathrm{day}^{-1}\right)$ or a normalprotein diet $\left(1.2 \mathrm{~g} \mathrm{~kg}^{-1} \mathrm{day}^{-1}\right)$ with the appropriate energy intake for each participant without masking.

The methods of minimisation for allocation were applied according to age, sex, serum creatinine, estimated GFR (eGFR), and urinary albumin and protein levels during the screening period. Both groups were instructed to meet the registered dietitian for 30 min every 3 months to assess and counsel dietary issues. After randomisation we followed the participants for approximately 3.5 years ( $1-5$ years). Every 3 months, all participants completed a 3 day food record to assess daily protein, energy and sodium intake. For this purpose, we used the fourth revised and enlarged edition of Standard tables of food composition in Japan [14]. The dietary protein intake was also assessed by urinary urea nitrogen excretion during $24 \mathrm{~h}$ urine collection every 3 months, using the formula of Maroni et al. [15]. To achieve dietary protein goals, dietary regimens were modified every 3 months or more as needed. The estimated protein intake during the study represents the mean of all measurements after randomisation.

Laboratory tests Blood and urine samples were brought to the central laboratory (SRL, Tokyo, Japan) and each clinical parameter was measured using the Hitachi 7170 analyzer (Hitachi High-Technologies, Tokyo, Japan) unless otherwise specified. GFR was estimated using the following modified MDRD formula for Japanese participants [16]: eGFR $\left(\mathrm{ml} \mathrm{min}{ }^{-1} 1.73 \mathrm{~m}^{-2}\right)=175 \times$ [serum creatinine $(\mu \mathrm{mol} / 1) / 88.4]^{-1.154} \times[\text { age }(\text { years })]^{-0.203} \times 0.741 \times(0.742$ if female), where serum creatinine estimated by an enzymatic method was calibrated. Creatinine clearance from a $24 \mathrm{~h}$ timed urine collection was calculated and corrected to a body surface area of $1.73 \mathrm{~m}^{2}$. Urinary excretion of protein and albumin was measured every 3 months in $24 \mathrm{~h}$ timed urine samples using an immunoturbidity assay and a pyrogallol red-molybdate complex (LX60000; Eiken
Chemical Co., Tokyo, Japan), respectively. Urinary nitrogen was measured by an enzymatic ultraviolet method every 3 months. Blood samples were obtained every 3 months to measure: renal function (blood urea nitrogen, creatinine, $\mathrm{Na}, \mathrm{K}, \mathrm{Cl}$, uric acid) by an autoanalyser; lipids (total cholesterol, triacylglycerol, HDL-cholesterol) by an enzymatic colorimetric method and a direct inhibition method, respectively; transferrin by an immunoturbidity assay (BN-II; Dade Boehring, Marbug, Germany); serum glucose by a glucose oxidase method; and $\mathrm{HbA}_{1 \mathrm{c}}$ by ion exchange HPLC (ADAMS A1c HA-8160; Aarkray, Kyoto, Japan).

Outcomes The primary outcomes were: (1) the annual change in eGFR and creatinine clearance; (2) the incidence of doubling of serum creatinine; and (3) the time to doubling of baseline serum creatinine. The secondary outcomes included the proportion of patients with ESRD requiring haemodialysis and the annual changes in urinary protein and albumin excretion. Quality of life was assessed annually using the SF-36 [17].

The secondary analysis, which was not based on a direct comparison of randomised groups, was performed to assess the biological dose-response relationship between actual protein intake and progression of type 2 diabetic nephropathy.

Statistical analysis An independent data and safety monitoring board monitored the study. The Lan-DeMets alpha spending-function method was used to adjust for interim analyses once a year. Four formal interim analyses were performed during the study period. The $p$ value for one interim analyses was set at $p=0.01$. Data handling and trial management were coordinated centrally by EPS (Tokyo, Japan).

The mean dietary protein intake between the low- and normal-protein diet groups was analysed using Wilcoxon's rank sum test. Dietary protein intake in the low- and normal-protein diet groups during the study was analysed by repeated measures ANOVA.

Analyses of the primary and secondary outcomes were performed according to the intention-to-treat principle; we included data from all randomised patients with the exception of the 24 participants lost or excluded between randomisation and study termination (Fig. 1). For continuous variables, the mean and standard deviation were calculated. Because of the skewed deviation, values for albuminuria and proteinuria are given as medians and interquartile ranges. In calculating the slopes of the rates of change of eGFR and creatinine clearance, linear regression analysis was used and included the data of patients who reached an endpoint. A minimum of 1 year follow-up with at least two measurements of serum and urinary creatinine 
Fig. 1 Design of the trial. Fifteen patients were lost during follow-up because they moved away or withdrew informed consent within 1 year of followup. Nine patients were excluded from analysis because they had less than two measurements of urinary nitrogen excretion and serum creatinine

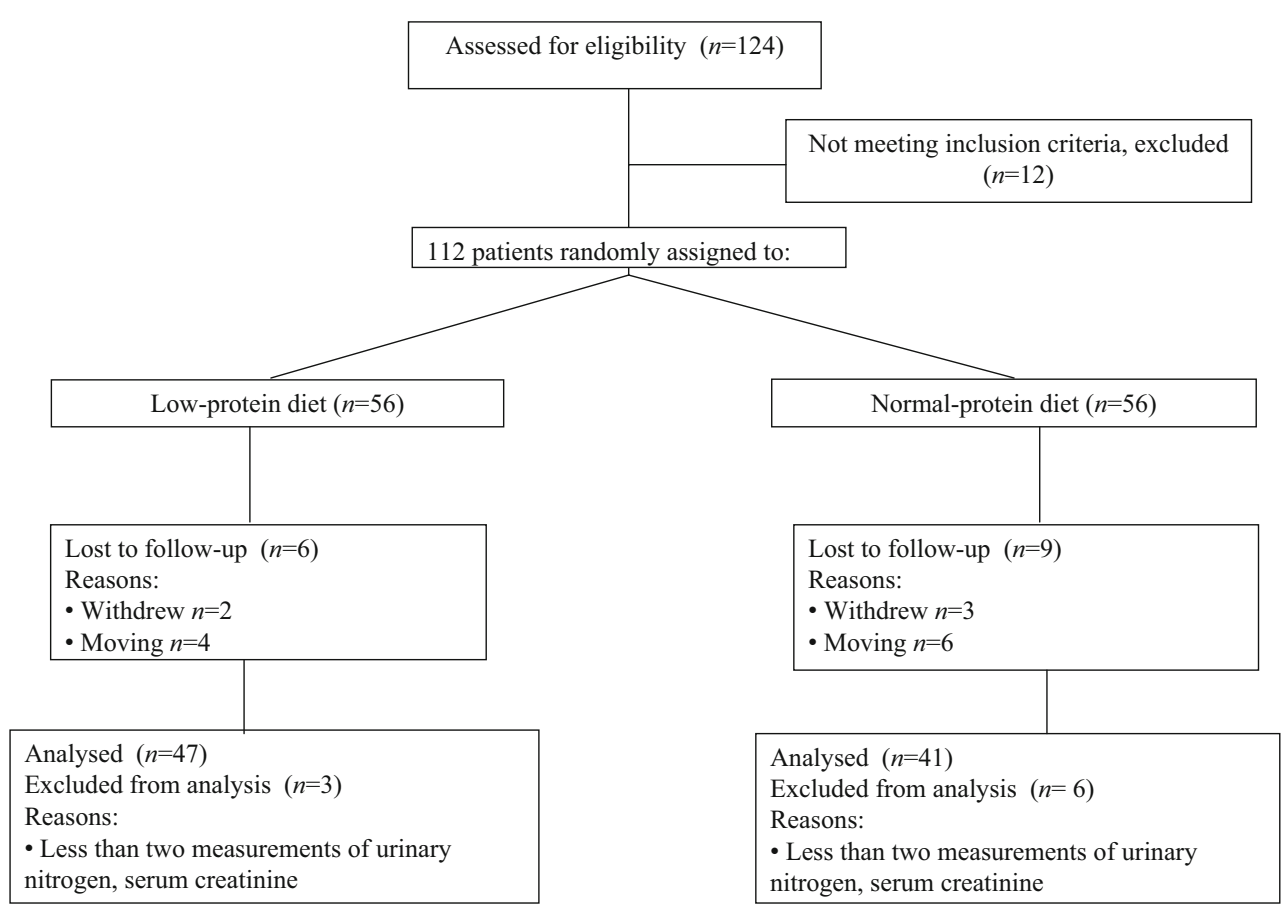

during the study period were aggregated in the slope analysis. Primary outcome values between groups were assessed by an analysis of covariance model, with lowprotein diet as a factor and baseline urinary protein, serum creatinine, $\mathrm{HbA}_{1 \mathrm{c}}$, systolic blood pressure and daily protein intake, in addition to age and sex, as covariates. The incidence of doubling of serum creatinine was compared with the $\chi^{2}$ test. The times to doubling of baseline serum creatinine and its components were compared by KaplanMeier survival curves and the log-rank test. Baseline serum creatinine was adjusted using Cox proportional hazards models with terms for the diet assignment. Secondary outcomes were compared with the $\chi^{2}$ test (for nonparametric data) or repeated measures ANOVA (for continuous data).

In secondary analysis, the differences between achieved protein intake and renal functions were determined using Pearson's correlation coefficient and Spearman's rank/correlation coefficient. To identify the factors associated with the doubling of serum creatinine, the potential risk factors such as systolic blood pressure, protein intake, sodium intake, $\mathrm{HbA}_{1 \mathrm{c}}$ and total cholesterol were included in the Cox proportional hazards model, adjusting for sex, age, urinary albumin excretion and serum creatinine.

All statistical tests were two-sided. For the final analysis of the primary endpoints and all other endpoints, a $p$ value of 0.05 or less was considered to indicate significance. Data were analysed using SAS 8.2 (Statistical Analysis System, Cary, NC, USA).

\section{Results}

Participants The baseline characteristics of the 112 type 2 diabetic participants with nephropathy who underwent randomisation were similar between low-protein diet and normal-protein diet groups (Table 1). The study was completed by 47 of the $56(84 \%)$ participants in the lowprotein diet group and by 41 of the $56(73 \%)$ participants in the normal-protein diet group (Fig. 1). In both groups, the reasons for dropping out were: loss of follow-up due to moving (ten participants); withdrawal of informed consent (five participants); and less than two measurements of dietary protein intake and of serum and urinary creatinine during the study period (nine participants).

Dietary assessment At randomisation, there was no difference in mean dietary protein intake between the two diet groups as assessed by a 3 day food record and a dietitian (lowprotein $1.0 \pm 0.3$ vs normal-protein $1.1 \pm 0.2 \mathrm{~g} \mathrm{~kg}^{-1} \mathrm{day}^{-1}$ ) and by estimates using $24 \mathrm{~h}$ urinary nitrogen excretion $(1.0 \pm 0.2$ vs $1.0 \pm 0.2 \mathrm{~g} \mathrm{~kg}^{-1} \mathrm{day}^{-1}$, respectively). During the study, the mean protein intake from the food record was significantly different between low- and normal-protein intake group $\left(0.9 \pm 0.2\right.$ vs $1.1 \pm 0.2 \mathrm{~g} \mathrm{~kg}^{-1} \mathrm{day}^{-1}$, respectively, $\left.p<0.0001\right)$, while the protein intake derived from $24 \mathrm{~h}$ urinary nitrogen excretion was similar between the two group $(1.0 \pm 0.2$ vs $1.0 \pm 0.2 \mathrm{~g} \mathrm{~kg}^{-1} \mathrm{day}^{-1}$, respectively, $p=0.16$ ). The mean protein intake estimated by urinary nitrogen excretion in the low-protein diet group was lower than that in the normalprotein group during the study period, but the difference was 
Table 1 Baseline characteristics of the participants

Unless otherwise stated, values are mean $\pm \mathrm{SD}$ or medians (interquartile range)

\begin{tabular}{lll}
\hline Variable & Low-protein diet $(n=56)$ & Normal-protein diet $(n=56)$ \\
\hline Age (years) & $57.5 \pm 7.8$ & $56.3 \pm 8.7$ \\
Male sex, $n(\%)$ & $33(58.9)$ & $33(57.1)$ \\
Height $(\mathrm{cm})$ & $160.4 \pm 8.5$ & $160.7 \pm 7.8$ \\
Weight $(\mathrm{kg})$ & $63.8 \pm 10.7$ & $62.9 \pm 10.5$ \\
Systolic blood pressure $(\mathrm{mmHg})$ & $138 \pm 21$ & $137 \pm 16$ \\
Diastolic blood pressure $(\mathrm{mmHg})$ & $77 \pm 11$ & $77 \pm 12$ \\
Serum creatinine $(\mu \mathrm{mol} / \mathrm{l})$ & $91.9 \pm 50.4$ & $98.1 \pm 45.1$ \\
eGFR $\left(\mathrm{ml}\right.$ min $\left.{ }^{-1} 1.73 \mathrm{~m}{ }^{-2}\right)$ & $63.5 \pm 26.9$ & $61.1 \pm 23.7$ \\
Urinary albumin $(\mu \mathrm{g} / \mathrm{min})$ & $488(214-1,359)$ & $527(325-1,364)$ \\
Urinary protein $(\mathrm{g} / \mathrm{day})$ & $1.1(0.4-3.2)$ & $1.2(0.5-2.9)$ \\
HbA ${ }_{1 \mathrm{c}}(\%)$ & $7.8 \pm 1.5$ & $7.5 \pm 1.7$ \\
Total cholesterol $(\mathrm{mmol} / \mathrm{l})$ & $5.7 \pm 1.1$ & $5.8 \pm 1.3$ \\
Triacylglycerol $(\mathrm{mmol} / \mathrm{l})$ & $1.8 \pm 0.9$ & $1.8 \pm 0.9$ \\
With hypertension $(\%)$ & 63.0 & 68.6 \\
\hline
\end{tabular}

not significant ( $p=0.14$ ) (Fig. 2a). This was in contrast to the significant difference between the two groups based on food record ( $p<0.0001)$ (Fig. 2b).

Primary outcomes The mean annual change in eGFR was $-6.1 \pm 6.5 \mathrm{ml} \mathrm{min}^{-1} 1.73 \mathrm{~m}^{-2}$ for the low-protein diet group, compared with $-5.8 \pm 5.7 \mathrm{ml} \mathrm{min}^{-1} 1.73 \mathrm{~m}^{-2}$ for the normal-protein diet group; the difference between the two groups was $-0.3 \mathrm{ml} \mathrm{min}-11.73 \mathrm{~m}^{-2}$ and not significant (95\% CI $-3.9,4.4 ; p=0.93)$. The mean annual change in creatinine clearance was $-0.163 \pm 0.159 \mathrm{ml} \mathrm{s}^{-1} 1.73 \mathrm{~m}^{-2}$ for the low-protein diet group, compared with $-0.157 \pm$ $0.125 \mathrm{ml} \mathrm{s}^{-1} 1.73 \mathrm{~m}^{-2}$ for the normal-protein diet group; the difference between the two groups was $-0.006 \mathrm{ml} \mathrm{s}^{-1}$ $1.73 \mathrm{~m}^{-2}$ and also not significant (95\% CI $-0.089,0.112$; $p=0.80)$. A doubling of serum creatinine was reached in 16 patients of the low-protein diet group (34.0\%), as compared with 15 in the normal-protein diet group (36.6\%), with a difference between the two groups of $-2.6 \% \quad(95 \%$ CI $-22.6,17.5 ; p=0.80)$. The time to doubling of serum creatinine was similar in both groups $(p=0.66)$ (Fig. 3$)$. The hazard ratio for the doubling of serum creatinine by Cox regression was $0.42(95 \%$ CI $0.042,4.22)$ for the lowprotein diet group.

Secondary outcomes The proportion of patients with ESRD was $6.4 \%$ in the low-protein diet group, compared with $7.3 \%$ in the normal-protein diet group, with a difference between the two groups of $-0.9 \%(95 \% \mathrm{CI}-0.11,0.10 ; p=$ 0.86). During the study period, the level of albuminuria in the low-protein diet group was not different from that in the normal-protein diet group (Fig. 4a). The level of proteinuria was also similar (Fig. 4b).
Associations of achieved protein intake with eGFR and creatinine clearance The secondary analysis, which was not based on a direct comparison of randomised groups, was performed to assess the biological dose-response relationship between actual protein intake and the progression of diabetic nephropathy in type 2 diabetes, without adjustment for other covariates. The lower protein intake, which was calculated by urinary nitrogen excretion (Fig. 5a) and the 3 day food record (Fig. 5b), was not associated with a slower deterioration of GFR. The correlational analysis using the annual change in creatinine clearance was also not conclusive with regard to the efficiency of low-protein diet, as measured by urea nitrogen excretion $(p=0.22)$ (Fig. 5c) and dietary record $(p=0.71)$ (Fig. 5d). In the multivariate model, adjusted for systolic blood pressure, protein and sodium intake, $\mathrm{HbA}_{1 \mathrm{c}}$ and serum total cholesterol during the study, systolic blood pressure was independently associated with the doubling of serum creatinine (Table 2).

Adverse events and quality of life During the study, one participant of the low-protein diet group died due to tuberculosis-linked sepsis and one participant of the normal-protein diet group died due to acute myocardial infarction. The difference in body weight between baseline and end of follow-up was $0.9 \mathrm{~kg}$ in the low-protein diet group and $0.2 \mathrm{~kg}$ in the normal-diet group, which was not significantly different between the two groups. During the study period, there was also no significant difference between the two groups in total energy (108.8 \pm 18.4 vs $\left.113.8 \pm 15.9 \mathrm{~kJ} \mathrm{~kg}^{-1} \mathrm{day}^{-1}\right)$ and sodium intake $(7.7 \pm 2.1 \mathrm{vs}$ $7.9 \pm 2.0 \mathrm{~g} /$ day) as determined from the 3 day food record. Furthermore, the level of transferrin was not significantly 


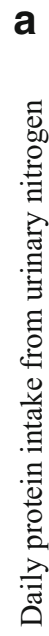

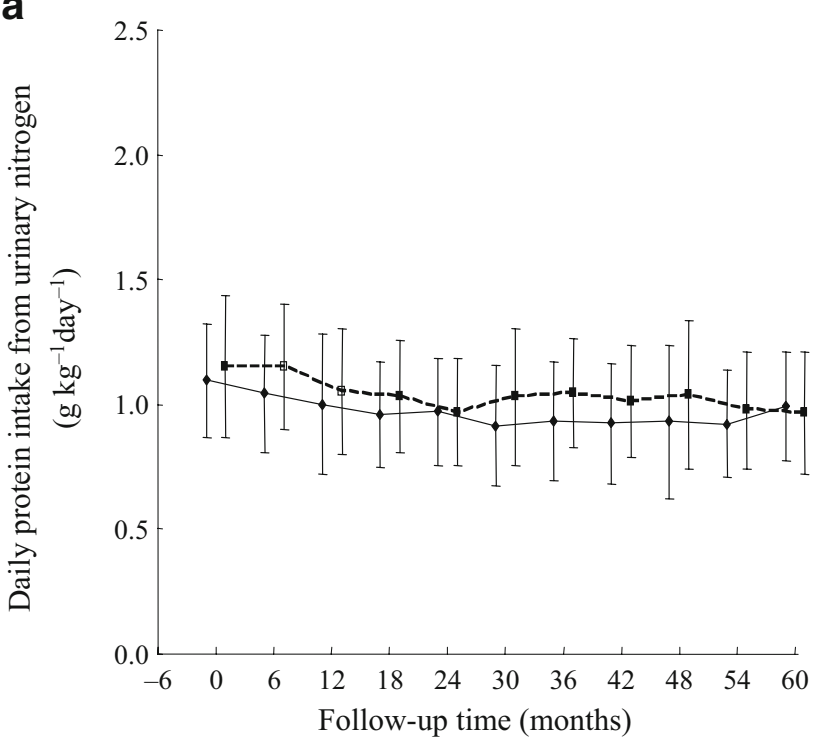

$\begin{array}{llllllllllll}\mathrm{L}(n): & 47 & 47 & 45 & 42 & 37 & 35 & 34 & 28 & 27 & 29 & 14\end{array}$

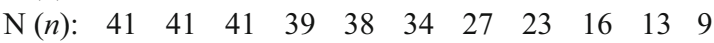

b

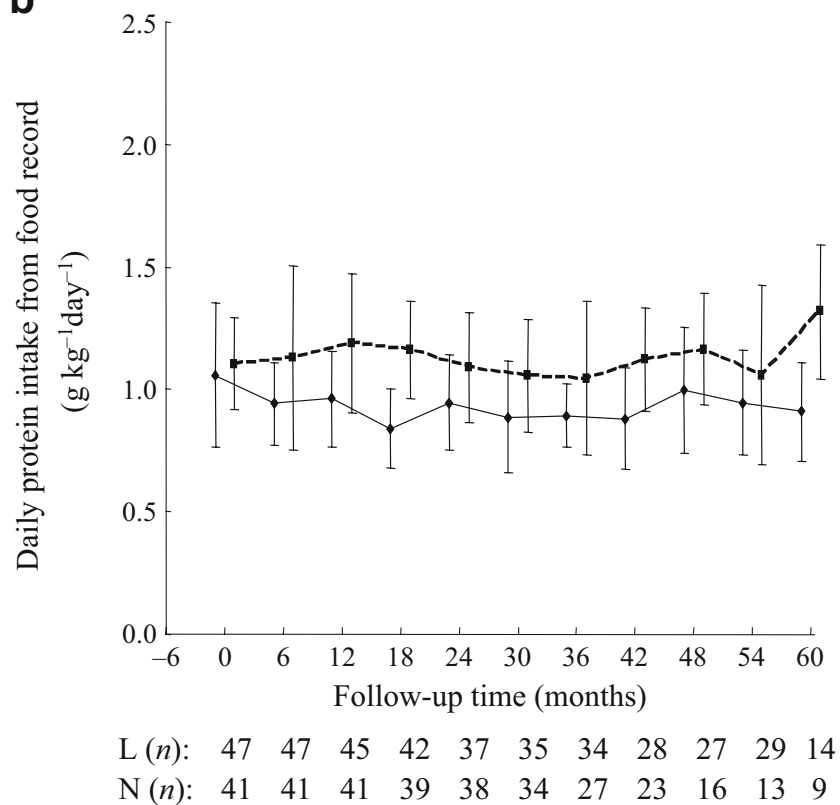

Fig. 2 Dietary protein intake in the low-protein diet (continuous lines) and normal-protein diet (dashed lines) groups estimated (a) from urinary nitrogen excretion and (b) from 3 day food record during the study. L ( $n)$, low-protein diet group ( $n$ participants); $\mathrm{N}(n)$, normalprotein diet group ( $n$ participants). Data are mean $\pm \mathrm{SD}$

different between the two groups during the study period $(p=0.83)$. There were no significant differences in healthrelated quality of life between the two groups during the study period, as measured by several SF-36 subscales (physical function, social function, physical role, emotional role, mental health, energy, pain and general health perceptions; $p>0.1$ ).

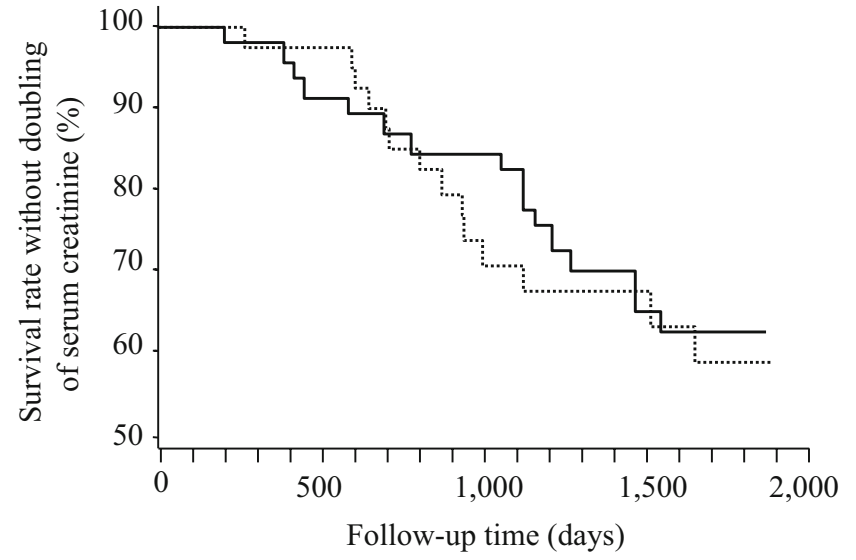

Fig. 3 Kaplan-Meier estimates of the primary endpoints from the study entry to time of doubling of baseline serum creatinine. The time to doubling was similar in both low-protein diet (continuous line) and normal-protein diet (dashed line). $p=0.66$ by logrank test

\section{Discussion}

We found that the low-protein diet was not associated with a better renal outcome than a normal-protein diet in patients with type 2 diabetes. Low-protein diet did not slow the rate of progression of nephropathy as estimated not only by the incidence of doubling of serum creatinine, but also by the time to doubling of serum creatinine concentration, compared with the normal-protein diet group. The mean annual change in eGFR and creatinine clearance was also similar between the two groups. The secondary analysis, which assessed the association between the rate of progression of diabetic nephropathy and the achieved protein intake, also failed to find a beneficial effect. Based on the timedependent Cox proportional hazards model, no renal benefit of low-protein diet was observed, although systolic blood pressure significantly influenced the progression of diabetic nephropathy. We thus interpret these results to indicate that a low-protein diet is probably not renoprotective in patients with type 2 diabetic nephropathy.

In a long-term study similar to ours, Pijls et al. reported that protein restriction is neither feasible nor efficacious [18], although they had recruited type 2 diabetic patients with microalbuminuria $(30-300 \mathrm{mg} /$ day) and relatively high albuminuria within the normo-albuminuric range (albuminuria $>20 \mathrm{mg} /$ day or detectable urinary albumin, i.e. albumin concentration $>6.5 \mathrm{mg} / \mathrm{l}$ ). In contrast, Hansen et al. performed a 4 year prospective, controlled trial with concealed randomisation to compare the decline in GFR and development of ESRD or death in type 1 diabetes patients with advanced diabetic nephropathy comparable to our participants [19]. Their usual-protein diet group consumed $1.02 \mathrm{~g} \mathrm{~kg}^{-1} \mathrm{day}^{-1}$ as compared with 0.89 (range 


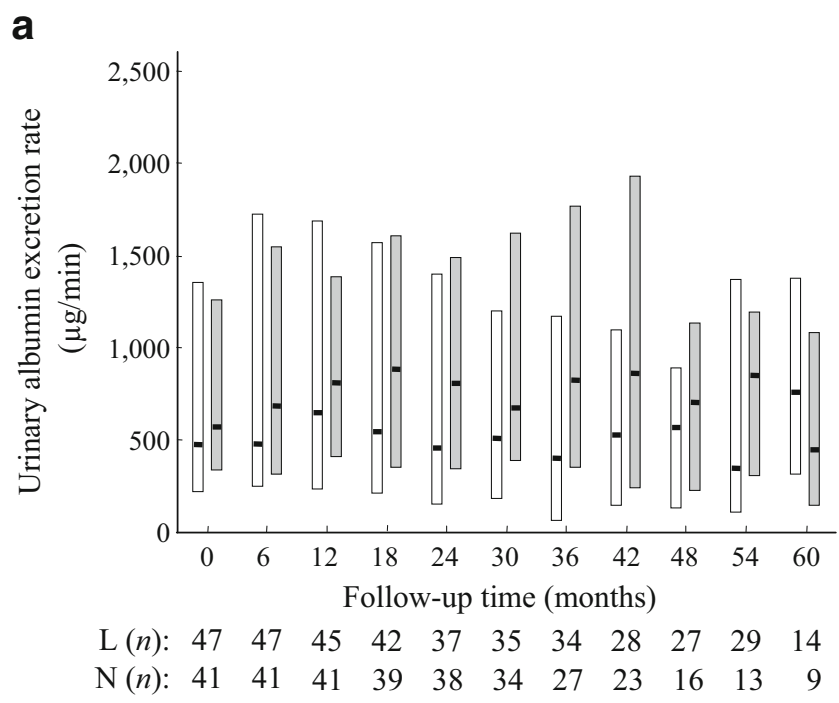

b

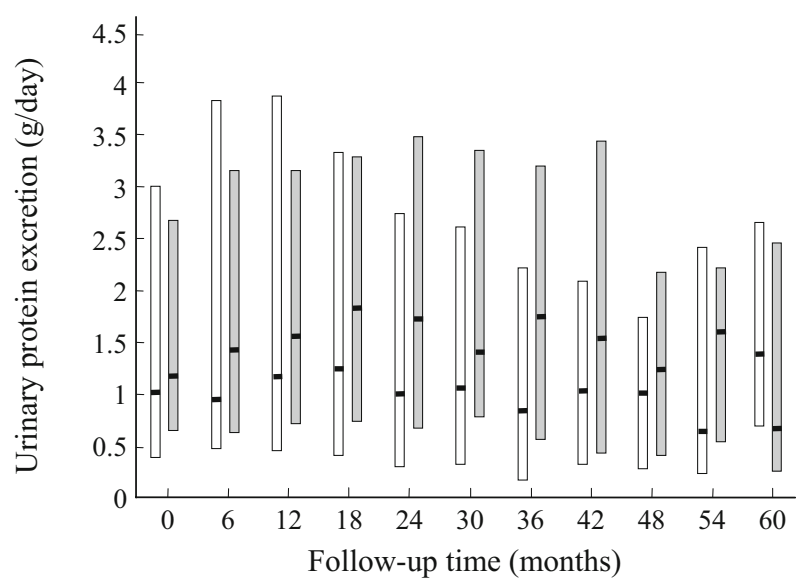

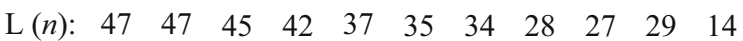

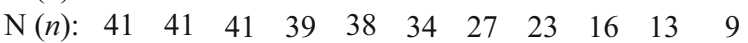

Fig. 4 The effect of low-protein diet (white columns) and normal protein intake (grey columns) on albuminuria (a) and proteinuria (b). Boxes indicate 25 th and 75 th percentiles of albuminuria or proteinuria. Horizontal lines indicate median. L $(n)$, low-protein diet group ( $n$ participants); $\mathrm{N}(n)$, normal-protein diet group ( $n$ participants)

0.83-0.95) $\mathrm{g} \mathrm{kg}^{-1} \mathrm{day}^{-1}$ in the low-protein diet group, a protein intake similar to our groups. However, in contrast to our findings, Hansen et al found that type 1 diabetic patients suffering from progressive diabetic nephropathy experienced a beneficial effect of moderately restricted dietary protein on the development of ESRD or mortality rates. The discrepancy might be due to the different types of diabetes and/or use of antihypertensive drugs, with almost $90 \%$ of patients in their study taking ACE-I. In our study, patients were instructed not to take ACE-I and/or ARBs, as these had not been approved for the treatment of diabetic nephropathy in Japan when this study was completed.
The prescribed protein intake in the low-protein group in our study (approximately $0.8 \mathrm{~g} \mathrm{~kg}^{-1} \mathrm{day}^{-1}$ ) resulted in a mean achieved protein intake of about $1.0 \mathrm{~g} \mathrm{~kg}^{-1} \mathrm{day}^{-1}$, as estimated by urinary nitrogen excretion, which was not statistically different from protein intake in the normalprotein diet. Since diabetic patients have to accept other restrictions to their diet regimen $[4,8,20]$, compliance to an additional low-protein diet could be reduced. The achieved level of long-term dietary protein restriction may reflect everyday life in an outpatient clinic set-up. Therefore, we cannot directly address the issue of whether the effects of lower protein intake such as $0.8 \mathrm{~g} \mathrm{~kg}^{-1} \mathrm{day}^{-1}$, the amount recommended in a nutritional statement by the American Diabetes Association (2008) [8], would be beneficial for type 2 diabetic patients with nephropathy. Non-adherence to the prescribed low-protein diet would result in underestimation of the true beneficial effect of the low-protein diet in the present study. However, it is not reasonable to assume that a lower protein intake equal to or less than $0.8 \mathrm{~g} \mathrm{~kg}^{-1} \mathrm{day}^{-1}$ would reduce the risk of progression of diabetic nephropathy, because the relationship between achieved protein intake $\left(0.55-1.6 \mathrm{~g} \mathrm{~kg}^{-1} \mathrm{day}^{-1}\right)$ and annual rate of eGFR decline as well as creatinine clearance decline also failed to produce any benefits for low-protein diet in our study. The MDRD, moreover, also failed to reach a conclusion on this issue [11-13]. Indeed, the recent longterm follow-up of the MDRD provides evidence that even very low protein diet, supplemented with keto acids and amino acids, increased the risk of death without the benefit of delaying progression of kidney diseases [21].

In the present study, we found that systolic blood pressure, rather than other variables such as blood glucose control, daily protein intake and sodium intake, played a major role in accelerating the progression of diabetic nephropathy during the follow-up period. Our results suggest that blood pressure control results in inhibition of progression of diabetic nephropathy [4, 22]. Furthermore, coexisistence of hypertension and type 2 diabetes is well known to accelerate the risk not only of development and progression of diabetic nephropathy, but also of cardiovascular disease outcome [22-25], meaning that control of high blood pressure is a major protective strategy against renal and cardiovascular outcomes in patients with diabetic nephropathy. Indeed, recent guidelines recommend treating type 2 diabetic patients with antihypertensive drugs, if their blood pressure is in the high-normal (previously normal) range (130-139/85-90 $\mathrm{mmHg}$ ), and sometimes even if blood pressure is in the normal and/or low prehypertensive range $(120-129 / 80-85 \mathrm{mmHg})[26,27]$.

Although previous experimental data suggested that the effects of low-protein diet, similar to treatment with an ACE-I or ARBs, are mediated through blockade of the renal renin-angiotensin system [28, 29], dietary protein 
Fig. 5 Correlation between achieved protein intake estimated (a) from urinary nitrogen excretion and the annual change in eGFR, and (b) from 3 day food record and the annual change in eGFR. c Correlation between achieved protein intake, estimated from urinary nitrogen excretion and (d) from from 3 day food record, and the annual change in creatinine clearance. The $p$ value was calculated using Spearman's rank correlation coefficient a

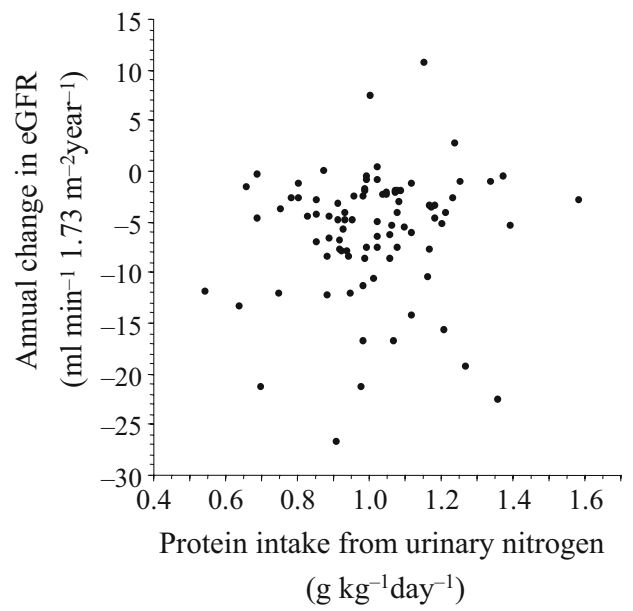

C

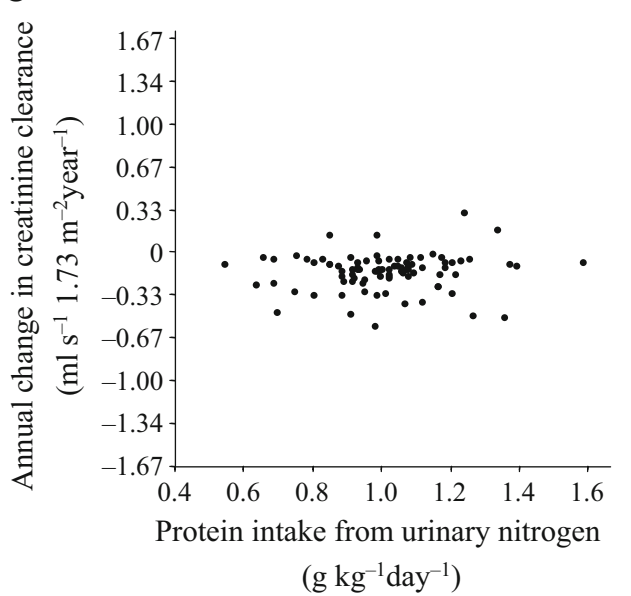

b

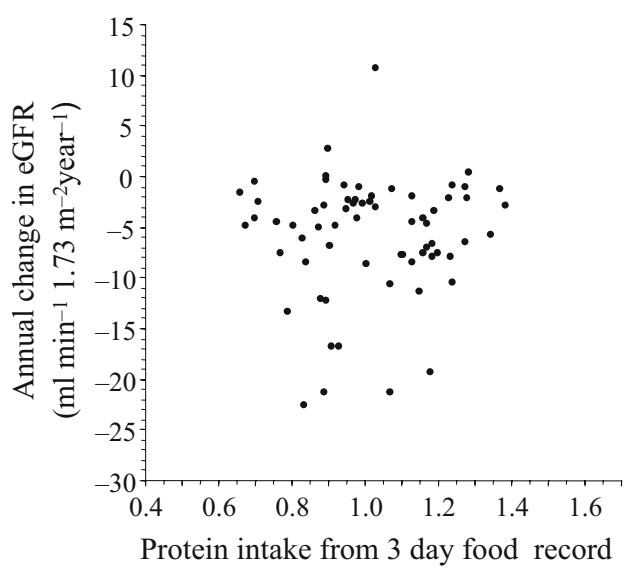

$\left(\mathrm{g} \mathrm{kg}^{-1}\right.$ day $\left.^{-1}\right)$

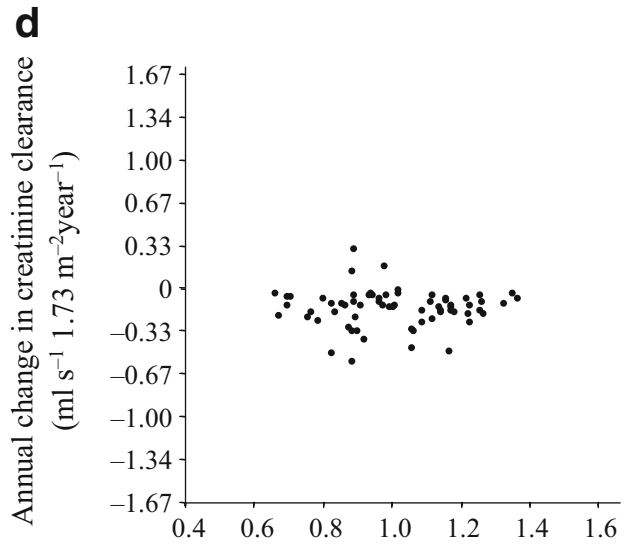

Protein intake from 3 day food record

$\left(\mathrm{g} \mathrm{kg}^{-1}\right.$ day $\left.^{-1}\right)$ restriction in the present study, where patients were not on ACE-I or ARBs, did not seem to act through the reninangiotensin system. At present, adding ACE-I or ARB to multifactorial intervention could reduce the progression of diabetic nephropathy, as reported in several studies [30-35]. Interestingly, a recent report by Parving et al. showed that without restriction of dietary salt or protein, the use of the renin inhibitor, aliskiren, in combination with an ARB efficiently reduces urinary albuminuria in diabetic patients with overt proteinuria [36].

In summary, it is extremely difficult to get patients to follow a long-term low-protein diet, and although overall protein intake was slightly (but not significantly) lower, it did not confer renoprotection. Our data may shed the light on the dietary management of diabetic nephropathy. One possible result is that protein restriction may not remain a main nutritional recommendation in clinical practice, because we now have a most valuable therapeutic strategy for reducing progression of diabetic nephropathy as well as cardiovascular events and mortality rates by using intensive multifactorial interventions such as lifestyle management, ACE-I or ARBs, and lipid-lowering drugs, as reported in the Steno-2 study [32, 33]. Without additional data, we must continue to base decisions on the current balance of evidence for and against the efficacy and safety of dietary protein restriction.
Table 2 Hazard ratios of factors associated with the doubling of serum creatinine

a The multivariate model was adjusted for the following baseline variables: sex, age, urinary albumin excretion and serum creatinine

\begin{tabular}{lcc}
\hline Variable & Hazard ratio $(95 \% \mathrm{CI})^{\mathrm{a}}$ & $p$ value \\
\hline Systolic blood pressure $(\mathrm{mmHg})$ & $1.1(1.02-1.14)$ & 0.012 \\
Protein intake $\left(\mathrm{g} \mathrm{kg}^{-1} \mathrm{day}^{-1}\right)$ & $1.8(0.07-44.64)$ & 0.73 \\
Sodium intake $(\mathrm{g} /$ day $)$ & $0.9(0.72-1.14)$ & 0.41 \\
$\mathrm{HbA}_{1 \mathrm{c}}(\%)$ & $0.9(0.59-1.23)$ & 0.49 \\
Total cholesterol (mmol/l) & $1.0(1.0-1.01)$ & 0.49 \\
\hline
\end{tabular}


Acknowledgements We thank the patients who participated in the study. We also thank the independent data and safety monitoring board for their support and helpful discussions: T. Nagasawa, S. Koshikawa, O. Sakai, Y. Shigeta, Y. Ohashi and S. Nakano. This study was supported by a research grant from the Ministry of Health, Labour and Welfare of Japan (to R. Kikkawa and H. Makino).

Duality of interest The authors declare that there is no duality of interest associated with this manuscript.

Open Access This article is distributed under the terms of the Creative Commons Attribution Noncommercial License which permits any noncommercial use, distribution, and reproduction in any medium, provided the original author(s) and source are credited.

\section{References}

1. Ritz E, Orth SR (1999) Nephropathy in patients with type 2 diabetes mellitus. N Engl J Med 341:1127-1133

2. United Renal Data System 2006 (2006) Annual data report. Available from www.usrds.org/slides 2006.htm, accessed in June 2009

3. Nakai S, Masakane I, Akiba T et al (2008) An overview of dialysis treatment in Japan (as of Dec. 31, 2006). J Jpn Soc Dial Ther 41:1-28

4. Sasso FC, De Nicola L, Carbonara O et al (2006) Cardiovascular risk factors and disease management in type 2 diabetic patients with diabetic nephropathy. Diabetes Care 29:498-503

5. Mandayam S, Mitch WE (2006) Dietary protein restriction benefits patients with chronic kidney disease. Nephrology (Carlton) 11:53-57

6. Kasiske BL, Lakatua JD, Ma JZ, Louis TA (1998) A metaanalysis of the effects of dietary protein restriction on the rate of decline in renal function. Am J Kidney Dis 31:954-961

7. Pedrini MT, Levey AS, Lau J, Chalmers TC, Wang PH (1996) The effect of dietary protein restriction on the progression of diabetic and nondiabetic renal diseases: a meta-analysis. Ann Int Med 124:627-632

8. Association AD (2008) Nutritional recommendations and interventions for diabetes. A position statement of the American Diabetes Association. Diabetes Care 30(Suppl 1):S61-S78

9. Johnson DW (2006) Dietary protein restriction as a treatment for slowing chronic kidney disease progression: the case against. Nephrology (Carlton) 11:58-62

10. Robertson L, Waugh N, Robertson A (2007) Protein restriction for diabetic renal disease. Cochrane Database Syst Rev (4): Art. no. CD002181. doi: $10.1002 / 14651858$.

11. Klahr S, Levey AS, Beck GJ et al (1994) The effects of dietary protein restriction and blood-pressure control on the progression of chronic renal disease. Modification of diet in renal disease study group. N Engl J Med 330:877-884

12. Levey AS, Greene T, Beck GJ et al (1999) Dietary protein restriction and the progression of chronic renal disease: what have all of the results of the MDRD study shown? Modification of Diet in Renal Disease Study group. J Am Soc Nephrol 10:2426-2439

13. Levey AS, Greene T, Sarnak MJ et al (2006) Effect of dietary protein restriction on the progression of kidney disease: long-term follow-up of the Modification of Diet in Renal Disease (MDRD) Study. Am J Kidney Dis 48:879-888

14. The resources council of the science and technology agency of Japan (1983) Standard tables of food composition in Japan, 4th edn. Printing Bureau, Ministry of Finance, Tokyo

15. Maroni BJ, Steinman TI, Mitch WE (1985) A method for estimating nitrogen intake of patients with chronic renal failure. Kidney Int 27:58-65
16. Imai E, Horio M, Nitta K et al (2007) Estimation of glomerular filtration rate by the MDRD study equation modified for Japanese patients with chronic kidney disease. Clin Exp Nephrol 11:41-50

17. Ware JE Jr, Sherbourne CD (1992) The MOS 36-item short-form health survey (SF-36). I. Conceptual framework and item selection. Med Care 30:473-483

18. Pijls LT, de Vries H, Donker AJ, van Eijk JT (1999) The effect of protein restriction on albuminuria in patients with type 2 diabetes mellitus: a randomized trial. Nephrol Dial Transpl 14:1445-1453

19. Hansen HP, Christensen PK, Tauber-Lassen E, Klausen A, Jensen BR, Parving HH (1999) Low protein diet and kidney function in insulin dependent diabetic patients with diabetic nephropathy. Kidney Int 55:621-628

20. Remuzzi G, Schieppati A, Ruggenenti P (2002) Clinical practice. Nephropathy in patients with type 2 diabetes. N Engl J Med 346:1145-1151

21. Menon V, Kopple JD, Wang X et al (2009) Effect of a very lowprotein diet on outcomes: long-term follow-up of the Modification of Diet in Renal Diasease (MDRD) Study. Am J Kidney Dis 53:208-217

22. Mogensen CE (1999) Microalbuminuria, blood pressure and diabetic renal disease: origin and development of ideas. Diabetologia 42:263-285

23. Simonson DC (1988) Etiology and prevalence of hypertension in diabetic patients. Diabetes Care 11:821-827

24. Grossman E, Messerli FH (2008) Hypertension and diabetes. Adv Cardiol 45:82-106

25. Ritz E, Dikow R (2006) Hypertension and antihypertensive treatment of diabetic nephropathy. Nat Clin Pract Nephrol 2:562-567

26. KDOQI (2007) KDOQI clinical practice guidelines and clinical practice recommendations for diabetes and chronic kidney disease. Am J Kidney Dis 49(Suppl 2):S1-S179

27. Khan NA, Hemmelgarn B, Herman RJ et al (2008) The 2008 Canadian hypertension education program recommendations for the management of hypertension: part 2 - therapy. Can J Cardiol 24:465-475

28. Brenner BM, Meyer TW, Hostetter TH (1982) Dietary protein intake and the progressive nature of kidney disease: the role of hemodynamically mediated glomerular injury in the pathogenesis of progressive glomerular sclerosis in aging, renal ablation, and intrinsic renal disease. N Engl J Med 307:652-659

29. Hostetter TH, Meyer TW, Rennke HG, Brenner BM (1986) Chronic effects of dietary protein in the rat with intact and reduced renal mass. Kidney Int 30:509-517

30. Lewis EJ, Hunsicker LG, Clarke WR et al (2001) Collaborative Study Group: renoprotective effect of the angiotensin-receptor antagonist irbesartan in patients with nephropathy due to type 2 diabetes. N Engl J Med 345:851-860

31. Brenner BM, Cooper ME, de Zeeuw D et al (2001) Effects of losartan on renal and cardiovascular outcomes in patients with type 2 diabetes and nephropathy. N Engl J Med 345:861-869

32. Gæde P, Vedel P, Larsen N, Jensen GVH, Parving H-H, Pedersen O (2003) Multifactorial intervention and cardiovascular disease in patients with type 2 diabetes. N Engl J Med 348:383-393

33. Gæde P, Lund-Andersen H, Parving HH, Pedersen O (2008) Effect of a multifactorial intervention on mortality in type 2 diabetes. N Engl J Med 358:580-591

34. Bakris GL, Williams M, Dworkin L et al (2000) Preserving renal function in adults with hypertension and diabetes: a consensus approach. National kidney foundation hypertension and diabetes executive committees working group. Am J Kidney Dis 36:646-661

35. Kimmel PL (2006) Update in nephrology and hypertension. Ann Int Med 144:281-285

36. Parving HH, Persson F, Lewis JB, Lewis EJ, Hollenberg NK; AVOID Study Investigators (2008) Aliskiren combined with losartan in type 2 diabetes and nephropathy. N Engl J Med $358: 2433-2446$ 